\title{
FATE OF SEAGRASS PRODUCTION AS ASSESSED BY CAGE EXPERIMENTS IN ENHALUS ACOROIDES BED IN GILIMANUK BAY, BALI, INDONESIA
}

\author{
M. Husni Azkab \\ Research Centre for Oceanography, Indonesian Institute of Sciences \\ Jl. Pasir Putih 1, Ancol Timur, Jakarta - 14430, Indonesia \\ e-mail:muha031@lipi.go.id; husniazkab@yahoo.co.id
}

\begin{abstract}
In 2006, the amounts of seagrass products floating away and depositing were measured by in situ cage experiments in a monospecific seagrass meadow of Enhalus acoroides in Gilimanuk Bay, Bali Island. Results showed that the average rates of the floating and depositing leaves were $4.03+0.28$ and $7.95+0.31$ gram dry weight shoot $^{-1}$ day $^{-1}$ respectively. To express it in another way, about $66.4 \%$ of seagrass production was deposited on the seagrass bed and $33.6 \%$ floated away from the seagrass bed.
\end{abstract}

Keywords: Seagrass, Enhalus acoroides, Fate of leaf production, Gilimanuk Bay, Bali

\section{INTRODUCTION}

High productivities of seagrass meadows have been reported hitherto from different parts of the world (McRoy and McMillan, 1977; Zieman and Wetzel, 1980; Hilman et al. (1989). It has also been pointed out that considerable amount of seagrass was reported offshore (Zieman et al., 1979; Bach et al., 1986). Part of this may be washed ashore at distant coast or deposited on the deep sea floor. The materials are important food resource for the benthic animals. However, in comparison with the knowledge on the decomposition process after settling, the data on processes of exportation and depositions are limited (Calagher et al., 1984; Greenway, 1976). Taking this important fact into consideration, a detailed in situ investigation has been carried out in order to estimate the amount of floating and depositing parts of seagrass at Gilimanuk Bay, Bali Island, Indonesia.

\section{MATERIALS AND METHODS}

Field cage experiments were carried out at seagrass bed of Gilimanuk Bay, Bali, in March 2006 (Fig. 1). A monospecific meadow of Enhalus acoroides lies on the sandy-mud bottom in Burung and Kalong Islands, Gilimanuk Bay. The seagrass bed lies at $5 \mathrm{~m}$ off shore, extending about $200 \mathrm{~m}$ in length and about $500 \mathrm{~m}$ in width along the sandymud beach. Four experimental cages were set in monospecific seagrass bed of $E$. acoroides at 0.50 $-2.0 \mathrm{~m}$ depth. Before setting up the cages in the seagrass bed, two kinds of experimental seagrass stands were prepared by cutting the surrounding seagrass shoots. One set of stand (cage 1 and 2) with an area of $1 \times 1 \mathrm{~m}$ is located in Burung Island and the second one (cage 3 and 4) with an area of $0.5 \times 0.5 \mathrm{~m}$ is located in Kalong Island. Then the litters in each stand were collected by hand and dried at $105^{\circ} \mathrm{C}$ for 24 hours and weighed.

In March 2006, a cage $(\mathrm{L}: \mathrm{W}: \mathrm{H}=1 \mathrm{~m}: 1 \mathrm{~m}$ : $0.8 \mathrm{~m})$, with $2 \mathrm{~mm}$ mesh net covering five sides except the bottom, was set on each experiment stand to prevent the loss of both floating and depositing parts of seagrass. In order to collect the floating and depositing leaves easily, a plastic fastener was provided at the top corner of three sides of the cage. In cage 1 and 2, only floating leaves and sheath at the ceiling of cages were collected carefully using a small plastic bag. In cage 3 and 4, the floating materials, depositing leaves and sheath (debris) at the bottom were also collected completely by hand with plastic bag. The collection was carried out every day over six days 


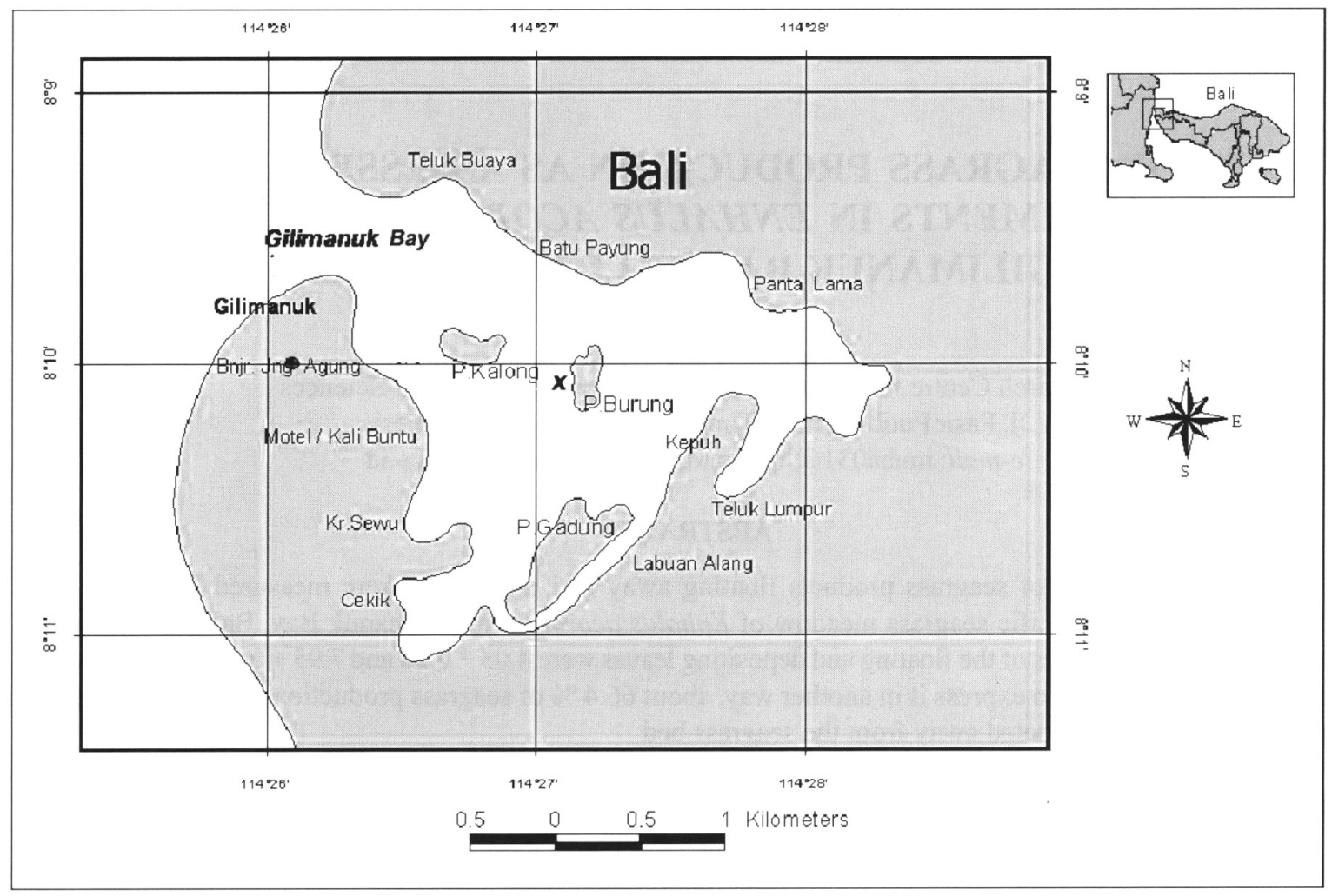

Figure 1. Map of experiment site (X), Gilimanuk Bay, Bali.

(6 times). The floating materials were divided into two categories, i.e. green (live) leaves including sheath and brown (dead) leaves. All materials were dried at $105^{\circ} \mathrm{C}$ for 24 hours and weighed.

After the experiments, both above-ground and under-ground parts were collected from Cage 3 and Cage 4 . The underground parts, especially up to $15 \mathrm{~cm}$ depth (Cage 3 ) and/or $25 \mathrm{~cm}$ depth (Cage 4) were collected by hand. After counting the number of shoots, seagrasses were divided into 3 parts, i.e. leaf, rhizome and root. Then, each part was dried at $105^{\circ} \mathrm{C}$ for 24 hours and weighed.

\section{RESULTS}

The number of shoots, biomass of each seagrass part and detritus (stock of litter) are presented in Tabel 1. The shoot densities of Cage 3 and 4 were 76 and $52 \mathrm{~m}^{-2}$, respectively, and these densities were only $1 / 2$ and $3 / 4$ of the mean density of the surrounding areas $\left(96\right.$ shoots $\mathrm{m}^{-2}$ ). The total biomass of cage 3 and cage 4 were 325.4 and $226.9 \mathrm{gDW} \mathrm{m}^{-2}$, respectively. The above and under-ground parts contributed fifty percent of the total biomass. The direct observations in the underlying sediments showed most part of the underground system of $E$. acoroides within $30 \mathrm{~cm}$ depth while root system was almost found in sediment deeper than $40 \mathrm{~cm}$.

The biomass of detritus (stock of litter) in Cage 3 and 4 were 20.7 and $24.1 \mathrm{gDW} \mathrm{m}^{-2}$ respectively, while that detritus on surrounding was $40.0 \mathrm{gDW}$ $\mathrm{m}^{-2}$, about two times that of in experiment cages.

The amount of floating and depositing (debris) materials collected every day are shown in Table 2. Among floating materials, the brown ones only consisted of dead leaves and the green ones consisted of green (live) leaves with sheath. The debris was occupied by only brown leaves. The amount of floating brown leaves ranged from 0.45 to $0.57 \mathrm{gDW}$ shoot ${ }^{-1} \mathrm{day}^{-1}$. The quantities of floating brown leaves in Cage 1 and 2 were relatively stable. But in Cage 3 and 4 were found more fluctuated. Nevertheless, the mean values in each cage were similar to each other (Table 2). The mean rates of floating green leaves in Cage 1,2 and 4 were similar and varied within a range of 0.22 to $0.32 \mathrm{gDW}$ shoot $^{-1} \mathrm{day}^{-1}$. The sheath with green leaves occupied only $20 \%$ of the floating leaves and only one or two sheath floated per day in these cages. In Cage 3, most part of floating materials were occupied by 5 or 6 sheath with 
Table 1. Biomass and litter of seagrass $\left(\mathrm{gDWm}^{-2}\right)$ in each experiment cage.

\begin{tabular}{|l|c|c|}
\hline \multicolumn{1}{|c|}{ Categories } & Cage 3 & Cage 4 \\
\hline Number of shoot & 76 & 52 \\
Dry weight (g) & & \\
$\quad$ Above ground (leaf, sheath) & $166.3(51.1 \%)$ & $121.4(53.5 \%)$ \\
Under ground (rhizome, root) & $149.1(48.9 \%)$ & $105.5(46.5 \%)$ \\
$\quad$ Total biomass & 325.4 & 226.9 \\
Litter & 20.7 & 24.1 \\
Total biomass/shoot & 4.4 & 4.5 \\
Above ground part/shoot & 2.62 & 2.81 \\
\hline
\end{tabular}

Table 2. Daily defoliation rate $\left(\mathrm{g} \mathrm{DW}\right.$ shoot $^{-1}$ day $\left.^{-1}\right)$ in the experiment cages.

\begin{tabular}{|c|c|c|c|c|}
\hline Days & Cage 1 (FL) & Cage 2 (FL) & Cage 3 (DL) & Cage 4 (DL) \\
\hline & & & & \\
1 & 0.45 & 0.57 & 2.77 & 2.72 \\
2 & 0.46 & 0.53 & 2.83 & 2.75 \\
3 & 0.45 & 0.55 & 2.92 & 2.96 \\
4 & 0.45 & 0.49 & 2.97 & 2.80 \\
5 & 0.49 & 0.55 & 2.98 & 2.85 \\
6 & 0.50 & 0.54 & 2.85 & \\
\hline Mean & & 0.54 & 2.89 & 2.84 \\
SD & 0.47 & 0.02 & 0.12 & 0.09 \\
\hline
\end{tabular}

$\mathrm{FL}=$ Floating leaf $\quad \mathrm{DL}=$ Depositing leaf

green leaves during the first six days. This made the floating rate of sheath with green leaves increased to two or three times larger than that of remaining cages. After this period, the rate in Cage 3 also decreased to the same level as in other cages. Total rate of floating leaves (including sheath), with the exception of the rate in Cage 3, ranged from 0.27 to $0.33 \mathrm{~g} \mathrm{DW} \mathrm{shoot}^{-1} \mathrm{day}^{-1}$.

The deposition rates (debris) in Cage 3 and 4 were fluctuated from 2.77 to $2.98 \mathrm{gDW}$ shoot $^{-1}$ day $^{-1}$ with the mean rates of 2.89 and 2.84 gDW shoot ${ }^{-1}$ day $^{-1}$, respectively. The mean rates of floating leaves, depositing leaves and defoliation, except the rate floating leaves in Cage 3, were shown in Table 3.

The debris (depositing) of the total defoliation and floating leaves, contributed $66.4 \%$ and $33.6 \%$, respectively. Two fifth of the floating leaves was green (live) and the rest was brown (dead) leaves.

\section{DISCUSSION}

The density of shoot at experiment site was less than that of the surrounding areas and that of the monospecific seagrass bed in Gilimanuk Bay. Dry weight of individual shoot was the same as those reported by the other authors and hence the biomass of this $E$. acoroides bed was also remained the same. The biomass also agreed well with the standing crops of other tropical seagrasses and that of the mixed seagrass bed in Lombok Island and Indonesian waters, where, the same type of cage experiments were done by Nojima et al. (1991); Nojima and Mukai (1991).

Among floating leaves, the amount of brown leaves was relatively stable in all cages. There is shown that the brown leaves may be detaching and floating away at constant rate like the depositing leaves. The green leaves, especially those with sheath, seem to broken off by accidental conditions such as storms and the action of herbivores (Greenway, 1976; Zieman et al., 1979; Nojima et al., 1991). However, in the cages excluding macro-herbivores, the daily rate of floating leaves was relatively constant with the exception of the first two days in Cage 3. During the first two days, floating of 5-6 sheaths with green leaves contributed $20 \%$ of the total floating green leaves. This is in contrast with the one or two sheaths in other cages. The reason is not known until know. However, the method used during the collection of debris seems to be one of the cause 
Table 3. The mean rates ( $\mathrm{gDW}$ shoot $\left.\mathrm{t}^{-1} \mathrm{day}^{-1}\right)$ of floating leaf, depositing leaf and defoliation.

\begin{tabular}{|l|c|c|c|}
\hline \multicolumn{1}{|c|}{ Categories } & Mean & Cages & No.of data \\
\hline Floating leaf (brown) & $2.69 \pm 0.12$ & All cages & $\mathrm{N}=24$ \\
Floating leaf (green) & $1.26 \pm 0.06$ & $1,2,4$ & $\mathrm{~N}=18$ \\
Total floating leaf & $4.03 \pm 0.28$ & $1,2,4$ & $\mathrm{~N}=18$ \\
Debris (depositing leaf) & $7.95 \pm 0.31$ & 3,4 & $\mathrm{~N}=12$ \\
Defoliation & $11.98 \pm 0.53$ & $1,2,3$ & $\mathrm{~N}=18$ \\
Defoliation & $8.85 \pm 0.15$ & 4 & $\mathrm{~N}=6$ \\
\hline
\end{tabular}

other than the effect of herbivores and storms (strong wind).

Azkab and Kiswara (1994) showed that leaf growth rate (production of leaf) was nearly equal to leaf defoliation in the same seagrass bed. Supposing that the production of above-ground part balances defoliation for a short time, daily defoliation, i.e. floating leaves and debris, equals to daily production. In the present study, the daily defoliation was $8.85 \mathrm{gDW} \mathrm{m}^{-2}$ day $^{-1}$ in Cage 4 . Contribution of sheath was less than $33.6 \%$ of the total defoliation, so that almost entire above-ground production (over $66.4 \%$ ) was occupied by leaf (blade). These production rates were almost the same with the production of $E$. acoroides in Kuta Bay (Azkab et al., 1999).

In adjacent area and Kuta Bay, studies using the marking method resulted the seagrass leaf production of $E$. acoroides at 1.24 gDW m ${ }^{-2}$ day $^{-1}$ (Azkab and Kiswara, 1994). The leaf defoliation in the present study was $2.89 \mathrm{gDW}$ $\mathrm{m}^{-2}$ day $^{-1}$ in Cage 3 and $2.84 \mathrm{gDW} \mathrm{m}^{-2}$ day $^{-1}$ in Cage 4. In spite of comparison on the defoliation of the same part (leaves), the rates could only account for $1 / 2$ of that the estimated rate by present cage experiment. The production rate of the monospecific seagrass bed of E. acoroides in Kuta Bay as recorded by Azkab and Kiswara (1994) was $2.5 \mathrm{gDW} \mathrm{m}^{-2} \mathrm{day}^{-1}$ using marking method. This rate is slightly high, but very close to that of the present study.

The production of seagrass bed is usually followed by decomposition process. If the daily deposition rate equals to daily decomposition rate, instantaneous fractional loss rate $(\mathrm{k})$ can be estimated as follows: $\mathrm{k}=\mathrm{L} / \mathrm{X}$, where $\mathrm{L}$ is income (daily deposition rate) and $\mathrm{X}$ is the amount of accumulation (stock of litter) at a steady level (Olson, 1963). While, the gross decomposition period of the $95 \%$ of litter under the condition without new deposition (T95) is estimated using this instantaneous fractional loss rate as follow: $\mathrm{T} 95=3 / \mathrm{k}$. Using these equations for the present study, $\mathrm{k}$ was estimated as 0.044 , gross decomposition period under the condition without new deposition was estimated as four days. The $\mathrm{k}$ and T95 values for Cage 3 and 4 were 0.079 and 5.0 days and 0.103 and 6 days, respectively. The lower values in Cage 3 and 4 are attributed to the lesser quantity of the debris. This is turned also to enhance the rate of the decomposition in Cage 3 and 4 . The T95 values of those cages were also only half of that of the surrounding area.

The instantaneous decomposition rate in Gilimanuk Bay was almost the same with that in Kuta Bay. This means that the decomposition process turns faster and the litter was quickly incorporated into detritus food chain in mono specific seagrass bed in Kuta Bay. On the contrary, in the present Gilimanuk seagrass bed, the decomposition process takes place relatively slow than in Gerupuk Bay (Azkab, 1988). During the decomposition process, the litter and debris might have been utilized by various kinds of deposit feeders. However, the macro detritus feeders, such us sea cucumber and strawberry conchs were very few in comparison with the seagrass bed in Kuta Bay. In similar cages experiment done in Kuta Bay, Lombok ca $34.7 \%$ of E. acoroides flown out as floating leaves and $65.3 \%$ of defoliation leaves contributed to debris. 
Acknowdgments. This study was sponsored by the Research Centre for Oceanography, Indonesian Institute of Sciences. I would like to thank to the Head of the Research Centre for Oceanography-LIPI and the Organizing Committee for giving me opportunity to attend the International Seminar on Coastal Marine Science, LIPI JSPS 2007, 3-5 August 2007, in Yogyakarta, Indonesia.

\section{REFERENCES}

Azkab, M.H., and W. Kiswara. 1994. Growth and production of seagrasses at Kuta Bay, Lombok island. In: W. Kiswara, M.K. Moosa and M. Hutomo, eds. The structure of biogical community of seagrass beds at South Lombok and its environmental condition RDCO-LIPI, Jakarta, 34 44 (in Indonesian).

Azkab, M.H. 1998. Fate of seagrass production as assessed by cage experiments in Enhalus acoroides in Gerupuk Bay, Lombok, Indonesia. Paper presented in the Fourth International Scientific Symposium, UNESCO/IOC/WESPAC, 2 - 7 February 1998, Okinawa, Japan, 11pp.

Azkab, M.H., H. Ogawa, and M. Muchtar. 1999. Fate of seagrass production as assessed by cage experiments in Enhalus acoroides in Kuta Bay, Lombok, Indonesia. In: K. Romimohtarto, S. Soemodihardjo and D.P. Praseno, eds. Proceeding $9^{\text {th }}$ JSPS Joint Seminar Science and Fisheries Science. LIPI-JSPS, Jakarta, 337-342.

Bach, S.D., G.W. Thayer, and M.W. La Croix. 1986. Export of detritus from eelgrass (Zostera marina) beds near Beaufort, North Carolina, US. Mar. Ecol. Prog. Ser. 28: 265-278.

Gallagher, J.L., H.V. Kibby and K.W. Skirvin. 1984. Detritus processing and mineral cycling in seagrass
(Zostera) litter in an Oregon salt marsh. Aquat Bot.20: 97-108.

Greenway, M. 1976. The grazing of Thalassia testudinum in Kingston Harbour, Jamaika. Aquat. Bot. 2: 117-126.

Hillman, K., D.I. Walker, A.W.D. Larkum, and A.J. McComb. 1989. Productivity and nutrient limitation. In: A.W.D. Larkum, A.J. McComb and S.A. Shepherd, eds. Biologi of seagrasses . 635-685.

McRoy, P., and C. MacMillan. 1977. Production ecology and physiology of seagrasses. In: C.P. McRoy and C. Helfferich, eds. Seagrass ecosystems, a scientific perspective . M.Dekker, Inc. New York, 53-87.

Nojima, S., and H. Mukai. 1991. Fate of seagrass production as assessed by cage experiments in a mono specific seagrass bed of Syringodium isoetifolium in Fiyi. In: I. Koike, ed. Development processes and material flow in tropical seagrass bed . Minstry of Educ.Cul. Sci. Japan (no page).

Nojima. S., H. Mukai, and M. Nishihira. 1991. Effect of sea urchin Tripneustes gratilla on the fate of seagrassa production. Aust. J. Mar. Fresh. Res. (Special issue) 42: 141-148.

Olson, J.S. 1963. Energy storage and balance of producers and decomposers in ecological systems. Ecology, 44: 322-331.

Zieman, J.C., G.W. Thayer, M.B. Robblee and R.T. Zieman. 1979. Production and export of seagrass from a tropical bay. In: R.J. Levingston, ed. Marine Science Vol. 10, Ecological processes in coastal and marine systems . Plemum Press, New York, 2133.

Zieman, J.C. and R.G.Wetzel. 1980. Productivity in seagrasses: methods and rates. In: R.C. Phllips and C.P. McRoy, eds. Handbook of seagrass biology. Garland STPM Press, New York: 89-116. 